\title{
Hubungan Pola Asuh dengan Pertumbuhan Anak 6-24 Bulan (Studi Perbandingan Antara Suku Melayu Jambi dan Suku Jawa di Kabupaten Muaro Jambi Propinsi Jambi)
}

\author{
Tuhu Perwitasari, Masrul, Nuzulia Irawati \\ Sekolah Tinggi Ilmu Kesehatan Baiturrahim Jambi \\ Email : tuhuedie@ymail.com
}

\begin{abstract}
One of factors that affect the growth of child is the nutritional status which determines the success in improving the quality of human resources. The health care and food in early life is crucial one to the growth and development of the child. This study aim to seek wheter the difference in child parenting between Jambi Malay and Javanese to the growth of children 6-24 months in Muaro Jambi District of Jambi Province is occured. The design of this study is observational analytic with cross sectional. The samples of the study were taken at two Working Areas of Health Care ; Muara Kumpeh for Jambi Malay and Markanding for Javanese Tribe. The population is children aged 6-24 months in both Working Areas of helath care and the number of samples taken in each area is 100 children. The data was collected through interviews and observations by researchers assisted by midwives in the helath care. Data processing was done using SPSS and data analysis using Mantel-Haenszel test.In this research, there is no disparity in parenting feeding methods $(p=0,227)$, while the analysis cannot be conducted on health parenting because there was a value of 0 . Furthermore, there is no difference in parenting hygiene $(p=0.828)$, and there is a significant difference in parenting psychosocial stimulation $(p=0.000)$ in Jambi Malay and Javanese. In this study it can be concluded that there is a significant difference in the growth of the child 6-24 month at the Jambi Malay and Javanese. In addition, there is no difference in Jambi Malays and Javanese parenting to the grow of the child aged 6-24 month. So that, It is suggested to provide counseling and health counseling to the mother and also involves other family members such as father.
\end{abstract}

Keywords:

Ethnic; Growth; Parenting.

\section{PENDAHULUAN}

Menurut Nurrizka dan Saputra (2013), salah satu faktor yang berpengaruh terhadap proses pertumbuhan anak adalah status gizi yang menentukan keberhasilan dalam peningkatan kualitas sumber daya manusia. Menurut WHO tahun 2002 penyebab utama kematian anak balita adalah masalah gizi buruk dengan angka 54 persen. Masalah gizi buruk dan kekurangan gizi merupakan masalah utama kesehatan di Negara berkembang seperti Indonesia (Kementrian Kesehatan RI, 2013).

Pada masa balita apabila mengalami kekurangan gizi mengakibatkan terjadinya keterlambatan atau terganggunya proses pertumbuhan, perkembangan otak dan menurunnya daya tahan tubuh terhadap infeksi. Kekurangan gizi juga berakibat terjadinya anemia pada balita sehingga akan meningkatkan angka morbiditas dan mortalitas pada balita. Hasil penelitian yang dilakukan terhadap suku anak dalam di Kabupaten Musi Bayuasin propinsi Sumatra Selatan masih terdapat 84 persen anak dari usia 0-9 tahun yang mengalami anemia (Sitorus, Oktarina, Ambarita, 2011).

Menurut Popkin dalam Mustapa, Sirajudin, Salam, (2013) ibu rumah tangga sebagai penentu dalam pengembagan diri anak prasekolah. Pada masyarakat Minangkabau sejak lama ibu sangat berperan dalam menghidupi anak-anaknya. Penelitian yang dilakukan oleh Putri, Sulastri, Lestari (2015), menggambarkan hubungan yang signifikan antara pola asuh dengan status gizi balita di wilayah kerja Puskesmas Nanggalo Padang.

Setiap masyarakat memiliki budaya, adat dan tradisi yang membentuk pola pikir dan emosi masyarakat. Budaya menentukan apa yang dapat diterima seperti makanan, pada kondisi seperti apa, kapan orang dapat atau tidak dapat makan, makanan apa yang menjadi pantangan dan lain sebagainya. Tradisi yang terkait dengan kebiasaan makan sebagai manifestasi tingkah laku berdasarkan budaya pada setiap suku (Khomsan, 2013).

Penelitian ini bertujuan untuk mengetahui Hubungan Pola Asuh dengan Pertumbuhan Anak 6- 24 Bulan (Studi Perbandingan Antara Suku Melayu Jambi dan Suku Jawa Di Kabupaten Muaro Jambi Propinsi Jambi).

\section{METODE PENELITIAN}

Penelitian ini dilakukan di Wilayah Kerja Puskesmas Muara Kumpeh dan wilayah kerja Puskesmas Markanding selama kurang lebih satu tahun. penelitian ini merupakan penelitian analitik observasional dengan rancangan cross sectional. Populasi penelitian ini adalah seluruh anak 6-24 bulan di Wilayah Kerja Puskesmas Muara Kumpeh dan wilayah kerja Puskesmas Markanding yang memenuhi criteria inklusi. Sampel diambil pada 2 wilayah kerja puskesmas dari 100 anak dengan Suku Melayu Jambi dan 100 anak Suku Jawa yang memenuhi kriteria penelitian. Peneliti melakukan wawancara dan 
observasi pola asuh anak setelah itu melakukan pengukuran berat badan, tinggi badan dan lingkar kepala. Analisa data menggunakan uji Mantel-Haenszel.

\section{HASIL DAN PEMBAHASAN}

Tabel 1 Perbedaan Pertumbuhan Anak 6-24 Bulan pada Suku Melayu Jambi dan Suku Jawa

\begin{tabular}{lccccc}
\hline $\begin{array}{l}\text { Pertum } \\
\text { buhan }\end{array}$ & Suku & $\begin{array}{c}\text { Melayu } \\
\text { Jambi }\end{array}$ & Suku & Jawa & Nilai $p$ \\
\hline $\begin{array}{l}\text { Normal } \\
\text { Tidak }\end{array}$ & 34 & 34,0 & 57 & 57,0 & 0,002 \\
normal & 66 & 66,0 & 43 & 43,0 & \\
\hline
\end{tabular}

Uji Chi-Square

Berdasarkan tabel 1 Hasil uji chi-square diperoleh nilai $p \leq 0,05 y a n g$ berarti terdapat perbedaan pertumbuhan anak 6-24 bulan antara Suku Melayu Jambi dengan Suku Jawa.

Tabel 2 Hubungan Pola Asuh Makan Suku Melayu Jamb dan Suku Jawa Terhadap Pertumbuhan Anak 6-24 Bulan

\begin{tabular}{|c|c|c|c|c|c|c|c|}
\hline \multirow{3}{*}{ Suku } & \multirow{3}{*}{$\begin{array}{c}\text { PA } \\
\text { Makan }\end{array}$} & \multicolumn{3}{|c|}{ Pertumbuhan } & \multirow{2}{*}{\multicolumn{2}{|c|}{ Total }} & \multirow[b]{2}{*}{ nilai $p$} \\
\hline & & \multicolumn{2}{|c|}{ Normal } & \multirow{2}{*}{$\begin{array}{c}\begin{array}{c}\text { Tidak } \\
\text { Normal }\end{array} \\
n\end{array}$} & & & \\
\hline & & $\mathrm{n}$ & $\%$ & & $\%$ & & \\
\hline \multirow{3}{*}{$\begin{array}{l}\text { Melayu } \\
\text { Jambi }\end{array}$} & $\begin{array}{l}\text { Baik } \\
\text { Kurang }\end{array}$ & 23 & 36,5 & 40 & 63,5 & 63 & 0,637 \\
\hline & Baik & 11 & 29,7 & 26 & 70,3 & 37 & \\
\hline & Baik & 40 & 55,6 & 32 & 44,4 & 72 & 0,808 \\
\hline \multirow[t]{2}{*}{ Jawa } & Kurang & & & & & & \\
\hline & Baik & 17 & 60,7 & 11 & 39,3 & 28 & \\
\hline
\end{tabular}

Uji Mantel-Haenszel

Tests of Homogeneity of the Odds Rasio

\begin{tabular}{lccc}
\hline & $\begin{array}{c}\text { Chi- } \\
\text { Scquared }\end{array}$ & $\mathrm{df}$ & $\begin{array}{c}\text { Asymp.sig } \\
\text { (2-sided) }\end{array}$ \\
\hline Breslow-Day &, 669 & 1 &, 414 \\
Tarrone's &, 669 & 1 &, 414 \\
\hline
\end{tabular}

Berdasarkan tabel 2 pada Suku Melayu Jambi hasil uji Mantel-Haenszel menunjukkan niilai $p>0,05$ yang berarti tidak terdapat hubungan antara pola asuh makan dengan pertumbuhan anak 6-24 bulan pada Suku Melayu Jambi. Pada Suku Jawa diperoleh nilai p> 0,05 disimpulkan bahwa tidak terdapat hubungan antara pola asuh makan dengan pertumbuhan anak 6-24 bulan pada Suku Jawa. Dari hasil ujinilai OR Homogeneity> 0,05 yang berarti tidak terdapat hubungan antara pola asuh makan terhadap pertumbuhan anak 6-24 bulan pada Suku Melayu Jambi dan Suku Jawa.

Tabel 3 Hubungan Pola Asuh Kesehatan Suku Melayu Jambi dan Suku Jawa Terhadap Pertumbuhan Anak 6-24 Bulan

\begin{tabular}{|c|c|c|c|c|c|c|c|}
\hline \multirow{3}{*}{ Suku } & \multirow{3}{*}{$\begin{array}{l}\text { Pola Asuh } \\
\text { Kesehatan }\end{array}$} & \multicolumn{4}{|c|}{ Pertumbuhan } & \multirow{3}{*}{ Total } & \multirow{3}{*}{ Nilai $p$} \\
\hline & & \multicolumn{2}{|c|}{ Normal } & \multicolumn{2}{|c|}{$\begin{array}{c}\text { Tidak } \\
\text { Normal }\end{array}$} & & \\
\hline & & $\mathrm{n}$ & $\%$ & $\mathrm{n}$ & $\%$ & & \\
\hline Melayu & Baik & 31 & 35,6 & 56 & 64,4 & 87 & 0,564 \\
\hline Jambi & Kurang Baik & 3 & 23,1 & 10 & 76,9 & 13 & \\
\hline \multirow{2}{*}{ Jawa } & Baik & 57 & 57,0 & 43 & 43,0 & 100 & \\
\hline & Kurang Baik & 0 & 0 & 0 & 0 & 0 & \\
\hline
\end{tabular}

Berdasarkan tabel 3 hasil uji MantelHaenszel menunjukkan niilai $p>0,05$ yang berarti tidak terdapat hubungan pola asuh kesehatan terhadap pertumbuhan anak 6-24 bulan pada Suku Melayu Jambi.Pada Suku Jawa semua responden memberikan pola asuh kesehatan yang baik, tetapi analisis tidak dapat dilakukan karna terdapat nilai 0 pada sel pola asuh kesehatan kurang baik Suku Jawa.

Tabel 4 Hubungan Pola Asuh Kebersihan Suku Melayu Jambi dan Suku Jawa Terhadap Pertumbuhan Anak 6-24 Bulan

\begin{tabular}{|c|c|c|c|c|c|c|c|}
\hline \multirow{3}{*}{ Suku } & \multirow{3}{*}{$\begin{array}{l}\text { Pola Asuh } \\
\text { Kebersihan }\end{array}$} & \multicolumn{4}{|c|}{ Pertumbuhan } & \multirow{3}{*}{ Total } & \multirow{3}{*}{ Nilai $p$} \\
\hline & & \multicolumn{2}{|c|}{ Normal } & \multicolumn{2}{|c|}{$\begin{array}{c}\text { Tidak } \\
\text { Normal }\end{array}$} & & \\
\hline & & $\mathrm{n}$ & $\%$ & $\mathrm{n}$ & $\%$ & & \\
\hline \multirow{2}{*}{$\begin{array}{l}\text { Melayu } \\
\text { Jambi }\end{array}$} & Baik & 32 & 36,8 & 55 & 63,5 & 87 & \multirow[t]{2}{*}{0,228} \\
\hline & Kurang Baik & 2 & 15,4 & 11 & 84,6 & 13 & \\
\hline \multirow{2}{*}{ Jawa } & Baik & 52 & 58,4 & 37 & 41,5 & 89 & \multirow[t]{2}{*}{0,619} \\
\hline & Kurang Baik & 5 & 45,5 & 6 & 54,5 & 11 & \\
\hline
\end{tabular}

Uji mantel-Haenszel

Tests of Homogeneity of the Odds Rasio

\begin{tabular}{lccc}
\hline & Chi-Scquared & df & $\begin{array}{c}\text { Asymp.sig } \\
(2-\text {-sided })\end{array}$ \\
\hline $\begin{array}{l}\text { Breslow- } \\
\text { Day }\end{array}$ &, 396 & 1 &, 528 \\
\hline Tarrone's &, 396 & 1 &, 529 \\
\hline
\end{tabular}

Berdasarkan tabel 4 pada suku melayu jambi hasil uji Mantel-Haenszel niilai $p>0,05$ yang berarti tidak terdapat hubungan pola asuh kebersihan terhadap pertumbuhan anak 6-24 bulan pada Suku Melayu Jambi. Pada Suku Jawa hasil uji statistic diperoleh nilai $p>0,05$ disimpulkan bahwa tidak terdapat hubungan antara pola asuh kebersihan terhadap pertumbuhan anak 6-24 bulan pada Suku Jawa.Dari hasil uji nilai OR Homogeneity> 0,05 yang berarti tidak terdapat hubungan antara pola asuh kebersihan terhadap pertumbuhan anak 624 bulan pada Suku Melayu Jambi dan Suku Jawa.

Tabel 5 Hubungan Pola Asuh Stimulasi Psikososial Suku Melayu Jambi dan Suku Jawa Terhadap Pertumbuhan Anak 6-24 Bulan

\begin{tabular}{|c|c|c|c|c|c|c|c|}
\hline \multirow{3}{*}{ Suku } & \multirow{3}{*}{$\begin{array}{l}\text { Pola Asuh } \\
\text { Stimulasi } \\
\text { Psikososial }\end{array}$} & \multicolumn{4}{|c|}{ Pertumbuhan } & \multirow{3}{*}{ Total } & \multirow{3}{*}{$\begin{array}{c}\text { Nilai } \\
p\end{array}$} \\
\hline & & \multicolumn{2}{|c|}{ Normal } & \multicolumn{2}{|c|}{$\begin{array}{c}\text { Tidak } \\
\text { normal }\end{array}$} & & \\
\hline & & $\mathrm{n}$ & $\%$ & $\mathrm{n}$ & $\%$ & & \\
\hline \multirow{2}{*}{$\begin{array}{l}\text { Melayu } \\
\text { Jambi }\end{array}$} & Baik & 24 & 34,3 & 46 & 65,7 & 70 & \multirow[t]{2}{*}{1,000} \\
\hline & $\begin{array}{l}\text { Kurang } \\
\text { Baik }\end{array}$ & 10 & 333 & 20 & 667 & 30 & \\
\hline \multirow{3}{*}{ Jawa } & Baik & 55 & 59,8 & 37 & 40,2 & 92 & \multirow[t]{3}{*}{0,125} \\
\hline & Kurang & & & & & & \\
\hline & Baik & 2 & 25,0 & 6 & 75,0 & 8 & \\
\hline
\end{tabular}

Uji mantel-Haenszel

Tests of Homogeneity of the Odds Rasio

\begin{tabular}{lrrr}
\hline & Chi-Scquared & df & Asymp.sig (2-sided) \\
\hline $\begin{array}{l}\text { Breslow- } \\
\text { Day }\end{array}$ & 2,425 & 1 & \\
\hline Tarrone's & 2,423 & 1 & \\
\hline
\end{tabular}

Pada tabel 5 terlihat pada suku melayu jambi niilai $p>0,05$ yang berarti tidak terdapat 
hubungan pola asuh stimulasi psikososial terhadap pertumbuhan anak 6-24 bulan pada Suku Melayu Jambi. Pada Suku Jawa hasil uji Mantel-Haenszel diperoleh nilai $p>0,05$ sehingga dapat disimpulkan bahwa tidak terdapat hubungan antara pola asuh stimulasi psikososial dengan pertumbuhan anak 6-24 bulan pada Suku Jawa.Nilai OR Homogeneity> 0,05 yang berarti tidak terdapat hubungan antara pola asuh stimulasi psikososial terhadap pertumbuhan anak 6-24 bulan pada suku Melayu Jambi dan Suku Jawa.

\section{Pembahasan \\ Perbedaan Pertumbuhan Anak 6-24 Bulan Pada Suku Melayu Jambi dan Suku Jawa}

BerdasarkanujiUji Chi-Square didapat bahwa nilai $p<0,05$, maka disimpulkan bahwa terdapat perbedaan pertumbuhan anak 6-24 bulan pada Suku Melayu Jambi dan Suku Jawa.

Pertumbuhan yang terhambat atau tidak sesuai dengan umur anak disebabkan karena kekurangan gizi baik saat masih dalam kandungan ataupun setelah lahir, apabila bayi tidak menyusu sampai 24 bulan atau diberikan ASI saja sampai dengan 6 bulan. Tinggi badan anak yang tidak optimal merupakan refleksi dari terganggunya keseimbangan gizi dalam waktu yang lama yang akan berpengaruh pada perkembangan otak (Jalal, 2009).

Etnis dan umur akan mempengaruhi status gizi dan pertumbuhan pada anak. Etnis dan umur juga bermanfaat untuk menentukan pemeriksaan fisik awal saat anak akan di rawat di rumah sakit dan sebagai penentu pemantauan kemajuan pengobatan gizi atau status gizi selama rawat inap (Kyle et al, 2015).

\section{Hubungan Pola Asuh dengan Pertumbuhan Anak 6-24 Bulan pada Suku Melayu Jambi dan Suku Jawa \\ Pola asuh makan dengan pertumbuhan anak 6-24 bulan}

Pola asuh makan pada Suku Melayu Jambi dan Suku Jawa sudah baik. Uji statistik diketahui nilai $p=0,227(p>0,05)$ yang berarti tidak terdapat perbedaan pola asuh makan Suku Melayu Jambi dan Suku Jawa.

Faktor yang mempengaruhi asupan nutrisi diantaranya adalah jenis MP-ASI yang diberikan, frekuensi pemberian, nafsu makan anak, waktu pemberian MP-ASI yang tidak sesuai umur dan pengasuhan makan yang diberikan bada anak. Rendahnya konsumsi ASI disebabkan oleh beberapa faktor status kesehatan dan gizi ibu, mekanisme hormonal, psikologis ibu, kelelahan fisik, ketersediaan waktu ibu untuk menyusui anak dan cara menyusui anak (Masrul, 2005).

Berdasarkan uji statistik menunjukkan nilai OR homogenitinya $>0,05(0,414)$ tidak terdapat perbedaan hubungan antara pola asuh makan dengan pertumbuhan anak 6-24 bulan pada Suku Melayu Jambi dan Suku Jawa. Pada Suku suku Melayu Jambi dan Suku Jawa Sudah memberikan pola asuh makan yang baik tetapi masih terdapat lebih dari separo yang mengalami pertumbuhan yang tidak normal.

Perhatian dan dukungan ibu terhadap anak dalam pemberian makan, persiapan dan penyimpanan makanan akan mendukung pertumbuhan anak. Peran keluarga terutama ibu sangat menentukan tumbuh kembang anak. Dukungan yang diberikan oleh ayah dalam pemberian makanan tambahan (PMT), pengambilan keputusan terkait kesehatan anak dan dukungan praktis dalam keseharian akan dapat meningkatkan jumlah asupan gizi anak terutama pada anak yang mengalami gizi kurang (Renyoet dkk, 2013, Symond, 2016).

\section{Pola asuh kesehatan dengan pertumbuhan anak 6-24 bulan}

Pola asuh kesehatan baik pada Suku Melayu Jambi lebih sedikit dibandingkan Suku Jawa semua responden telah memberikan pola asuh kesehatan baik. Hasil Uji Chi-Square tidak dapat digunakan karna tidak memenuhi kaedah uji yaitu ditemukannya nilai observasi 0 .

Tidak terjangkaunya pelayanan kesehatan (karna jarak dan atau tidak mampu membayar), kurangnya pendidikan dan pengetahuan merupakan kendala masyarakat dan keluarga dalam memanfaatkan pelayanan kesehatan. Hal tersebut akan berdampak pada status gizi anak (Ayu, 2008).

Pertumbuhan anak sangat di pengaruhi oleh faktor komposisional (individu) dan faktor konseptual (keluarga dan tenaga kesehatan) puskesmas sebagai penyedia pelayanan tingkat dasar di kecamatan. Pendidikan ibu yang tidak tamat SMP, jumlah saudara $\geq 3$ orang dan penanganan sampah yang kurang baik juga akan meningkatkan resiko gizi buruk. Pelaporan yang kurang baik yang dilakukan oleh tenaga kesehatan juga dapat meningkatkan resiko gizi buruk pada balita (Setyawati dkk, 2015).

Pola asuh kebersihan dengan pertumbuhan anak 6-24 bulan

Dari Uji statistik diketahui nilai $p=0,828$ ( $p$ $>0,05)$ yang berarti tidak terdapat perbedaan pola asuh kebersihan Suku Melayu Jambi dan Suku Jawa. penelitian yang dilakukan oleh Sumanto (2010) kurangnyapemahaman penting menjaga kesehatan anak khususnya mencegah terjadinya infeksi cacing dengan membiarkan saja anak bermain dikebun dan halaman rumah dengan berkotor-kotoran dengan tanah. Setelah selesai bermain anak hanya dianjurkan mencuci tangan dan kaki di sumur tanpa menggunakan sabun. 
Dari hasil uji perbedaan diperoleh nilai OR homogenitinya $>0,05(0,528)$ sehingga dapat disimpulkan bahwa tidak terdapat perbedaan hubungan pola asuh kebersihan terhadap pertumbuhan anak 6-24 bulan pada Suku Melayu Jambi dan Suku Jawa.

Praktek kebersihan yang tidak baik dalam keluarga harus diperbaiki dan diusahakan untuk melaksanakan yang benar sehingga terbebas dari penyakit. Diharapkan ibu dan ayah sebagai contoh dalam mempraktekkan dan mengembangkan sikap hidup bersih dan sehat seperti mandi 2 kali sehari, mencuci tangan dengan sabun sebelum dan sesudah makan juga setelah $B A B$, menyikat gigi setelah sarapan dan sebelum tidur dan membuang sampah pada tempatnya (Husin, 2008).

Pola asuh stimulasi psikososial dengan pertumbuhan anak 6-24 bulan

Mayoritas pola asuh stimulasi psikososial Suku Melayu Jambi dan Suku Jawa sudah baik. Dari Uji statistik diketahui nilai $p<0,05(0,000)$ yang berarti terdapat perbedaan pola asuh stimulasi psikososial Suku Melayu Jambi dan Suku Jawa.

Bermain merupakan suatu aktifitas dimana anak dapat mempraktekkan ketrampilan, mengekpresikan pemikiran. Memberikan stimulasi dalam kemampuan ketrampilan, kognitif dan afektif maka seharusnya diperlukan suatu bimbingan, mengingat bermain bagi anak merupakan suatu kebutuhan, seperti halnya kebutuhan makan, kebutuhan akan rasa aman, kasih sayang dan lain-lain (Hidayat, 2011).

Dari hasil uji perbedaan di peroleh nilai OR homogenitinya $>0,05 \quad(0,119)$ sehingga dapat disimpulkan bahwa tidak terdapat perbedaan hubungan pola asuh stimulasi psikososial terhadap pertumbuhan anak 6-24 bulan pada Suku Melayu Jambi dan Suku Jawa. Pada umumnya responden telah memberikan pengasuhan yang baik terhadap stimulasi psikososial.

\section{SIMPULAN}

Tidak terdapat perbedaan pola asuh Suku Melayu Jambi dan Suku Jawa terhadap pertumbuhan anak 6-24 bulan di Kabupaten Muaro Jambi.

\section{DAFTAR PUSTAKA}

Ayu, SD. Pengaruh Program Pendampingan Gizi Terhadap Pola Asuh, Kejadian Infeksi dan Status Gizi Balita Kurang Energi Protein Tesis. Universitas Diponegoro. Semarang. 2008.

Hidayat, AAA. Pengantar IImu Kesehatan Masyarakat Untuk Pendidikan Kebidanan. Jakarta: Salemba Medika. 2011.

Husin, CR. Hubungan Pola Asuh Anak Dengan Status Gizi Balita Umur 24-59 Bulan Di
Wilayah Terkena Stunami Kabupaten Pidie Propinsi Nangroe Aceh Darussalam. Tesis. Universitas Sumatera Utara. Medan. 2008.

Jalal, F. Pengaruh Gizi dan Stimulasi Psikososial Terhadap Pembentukan Kecerdasan Anak Usia Dini: Agenda Pelayanan Tumbuh Kembang Anak Holistik-Integratif. Universitas Andalas. 2009.

Kyle, UG. Earthman, CP. Pichard, C. Coss-Bu, JA. Body Composition During Growth In Children: Limititions and Perspective of Bioelectrical Impedance Analysis. European Journal of Clinical Nutrition. 2015.

Kementerian Kesehatan RI. Riset Kesehatan Dasar RISKESDAS Tahun 2013. 2013.

Khomsan, A. Riyadi, H. Marliati, SA. Ketahanan Pangan dan Gizi Serta Mekanisme Bertahan Pada Masyarakat Tradisional Suku Ciptagelar di Jawa Barat. Jurnal IImu Pertanian Indonesia (JIPI).Fakultas Ekologi Manusia IPB. Bogor. 2013.

Masrul. Kajian Sumber Daya Pengasuhan Terhadap Tumbuh Kembang Bayi Usia 612 Bulan Pada Keluarga Etnik Minangkabau Di Pedesaan Propinsi Sumatera Barat. Disertasi. Universitas Airlangga. 2005.

Mustapa, Y. Sirajudin, S. Salam, A. Analisis Faktor Determinan Masalah Gizi Pada Anak Balita di Wilayah Kerja Puskesmas Tillote Kecamatan Tilango Kabupaten Gorontalo Tahun 2013. 2013.

Nurrizka, RH. Saputra, W. Arah dan Strategi Kebijakan Angka Kematian Ibu (AKI), Angka Kematian Bayi (AKB) dan Angka Kematian Balita (AKABA) di Indonesia. Prakarsa Policy Papers/ Public Policy. 2013

Putri, RF. Sulastri, D. Lestari, Y. Faktor-Faktor yang Berhubungan dengan Status Gizi Anak Balita di Wilayah Kerja Puskesmas Nanggalo Padang. Jurnal Kesehatan Andalas. 2015.

Renyoet, BS. Hadju, V. Rochiniwati, ST. Hubungan Pola Asuh dengan Kejadian Stunting Anak Usia 6-23 Bulan di Wilayah Pesisir Kecamatan Tallo Kota Makassar.Fakultas Kesehatan Masyarakat. Universitas Hasanuddin Makassar. 2013.

Sitorus, H. Oktarina, R. Ambarita, PL. Malaria Pada Anak di Desa Pagar Desa (Pemukiman Suku Anak Dalam) di Kabupaten Musi Banyuasin Propinsi Sumatera Selatan. Media Litbang Kesehatan Volume 21. 2011.

Symond, D. Pengaruh Suplementasi Makanan Berbasis Lokal dan Optimalisasi Dukungan Ayah Terhadap Perubahan 
Kadar Albumin, Hemoglobin, Immunoglobulin A, dan Antropometri Pada Anak Gizi Kurang Di Kabupaten Padang Pariaman. Disertasi. Universitas Andalas. Padang. 2016.

Setyawati, B. Pradono, J. Rachmalina, R. Peran Individu, Rumah Tangga dan Pelayanan Kesehatan Dasar Terhadap Status Gizi Buruk Pada Balita di Indonesia. Media Litbangkes. Kemenkes RI. 2015.

Sumanto, D. Faktor Resiko Infeksi Cacing Tambang Pada Anak Sekolah. Tesis. Universitas Diponegoro. Semarang. 2010. 